\title{
The Relation Between Tourism, Local Development and Insularity: Case Study of Southern Aegean, Greece
}

\author{
Christos Pallis \\ Hellenic Open University, Patra, Greece \\ Andreas Prasinos \\ Region of South Aegean, Syros, Greece \\ Petros Pallis \\ University of Piraeus, Piraeus, Greece
}

\begin{abstract}
Greece as a significant tourist destination showed a considerable increase (5.1\%) in tourist arrivals in 2016, despite intense geopolitical upheaval, especially in the area of South-East Aegean. It is noteworthy that the main volume of tourism proceeds in Greece was generated by its insular regions, despite the intense problems faced by insularity, and by the insular Region of Southern Aegean in particular, despite the heavy refugee flows due to its geopolitical position. However, how is insularity affected by the new hyper-taxation of the islands through the increase of value added tax in insular local development and tourism? Is insular economy strong enough to withstand the increased and intensely varying international challenges? In this paper, after realistically depicting the official and published national tourism results for 2016, it is presented the immediate policy, institutional and destination management actions required in the Region of Southern Aegean so that it might be able to respond adequately to the new European or global tourism challenges, and act as the steam engine of the Greek tourism, pulling the broader Greek tourism development forward.
\end{abstract}

Keywords: insularity, destination management, tourism, Region of Southern Aegean, Greece

\section{Introduction}

Only a few months ago, specifically on May 27, 2017, the Bank of Greece (2016) published the aggregate data of the tourism industry in Greece for the previous year, which clearly shows that the main volume of proceeds has been generated in the insular regions. In the European Union (EU), an insular region is part of a member state that is surrounded by sea, has no ground connection with any continental area, and is not the capital city of the country in question (Spilanis, Akrikopoulou, Gakis, Michailidis, \& Niarchos, 2010).

However, the insular regions can further increase their income, thus pulling the overall GDP (\$194.6 billion) of Greece forward, a most welcome development in this period of financial crisis we are experiencing. What is the destination management of the insular regions of Greece that must be followed as regards the insular policy of Greece? How can the problem of intense insularity be addressed, so as to enable further tourism development?

Christos Pallis, Researcher, Department of Social Sciences, Hellenic Open University. Email: pallis@apopsi.gr.

Andreas Prasinos, Researcher, Region of South Aegean.

Petros Pallis, Researcher, Department of Maritime Studies, University of Piraeus. 
In the first section, we will focus on insularity, not only on the way it is perceived by the EU, but also on its effect on Greece, and on tourism in particular. The destination management of any insular destination requires that insularity be clearly defined, as it critically affects the insular tourism industry worldwide. We will present the economic footprint of tourism on the local insular economy, focusing on the abolition of the recently reduced value added tax (VAT) on islands. We will also present the most important official statistical data for the tourist period of 2016.

Finally, in the second section, we will focus on the particular case study in the Region of Southern Aegean (RSA) with SWOT analysis (strengths, weaknesses, opportunities, threats), suggestions on its destination management, and a presentation of the new updated tourism promotion, in correlation with the refugee issue (Georgopoulos, 2013).

\section{Literature Review}

\section{"Insularity" and Tourism}

By way of introduction, we should mention that insularity is a new term, originating from the Latin word "insula", which means "island". The term refers to the particular characteristics of insular areas (usually insular regions) that involve natural and socio-economic elements (Sarantakos, 2015).

In analyzing insularity, one must note that in general, insularity is an "aggravating" factor, which causes uneven development of the productive capacity and spatial differentiation of income and living conditions. The major factors that affect the intensity of insularity have to do with the external (as to the continental country) and internal (as to the largest island of an island complex) seclusion of each island, its natural size, its socio-economic features, the distance from the nearest continental Dynamic Urban Centre, etc. (Papadaskalopoulos, 2016).

\section{How Does the EU Perceive Insularity?}

In the EU, the moral basis for an insular policy is reflected in the following adage: "Treat equals equally and unequals unequally in proportion to their differences". In other words, there is a breach of the principle of equality when those who are not equal are treated in the same manner (Secretariat General for the Aegean and Island Policy, 2012).

In more detail, the characteristics of insularity, which combine natural and socio-economic elements, involve relative seclusion, the sensation of uniqueness, incomplete access to the markets and to public services, and finally, problems in transportation. This definition was given by: the Parlement Europeen, Resolution sur les problemes des regions insulaires de l' Union Europeenne, A4-0118/98 (Spilanis et al., 2010).

Therefore, placing great importance on social cohesion with the rest continental Greece, the EU has stated in its Partnership Agreement for the Development Framework of Greece 2014-2020 (National Strategic Reference Framework) that it looks forward to "reinforcing social cohesion and the principles of sustainable development” (European Social Fund in Greece, 2017).

\section{Greek Insularity and Tourism}

Greece, as a par excellence insular country, has the highest rates of insular population and area of all EU countries (Spilanis et al., 2010), with one of its basic administrative structures being the insular regions, i.e., the part of the country that includes a group of islands or a large island, whose features, mainly the socio-economic ones, differentiate it from the other continental regions (Spilanis et al., 2010). 
The position of the Greek island area in the European islands is shown in Figure 1 as follows.

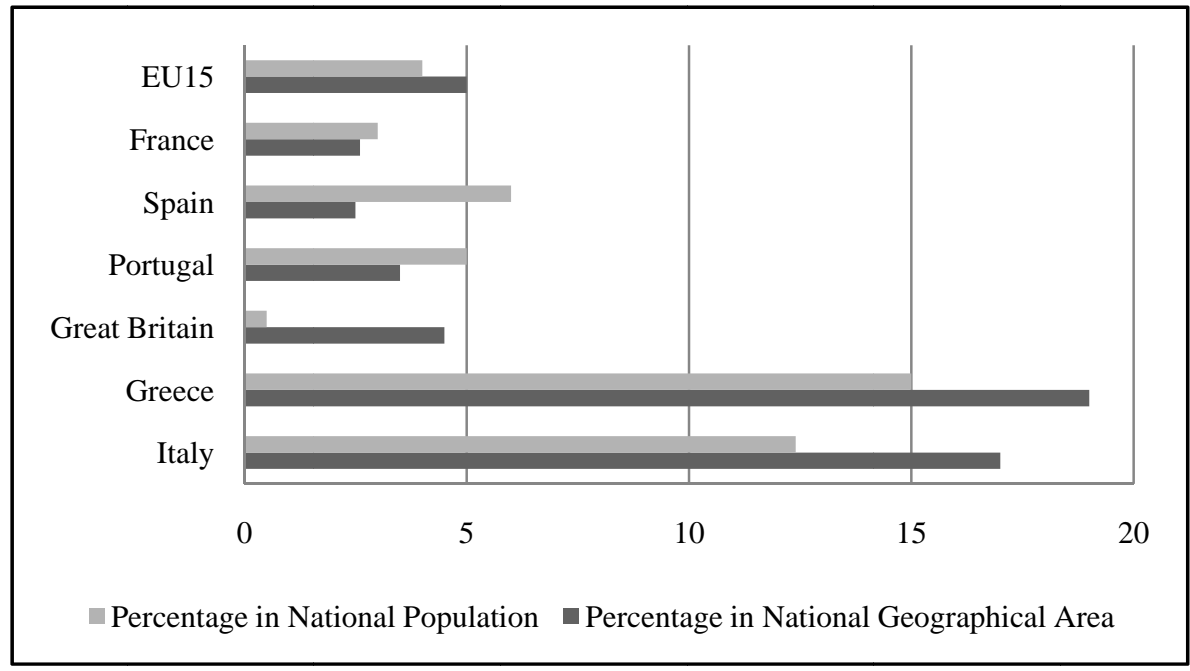

Figure 1. The position of the Greek island area in the European islands. Source: Institution of Municipalities (2016).

Based on Figure 1, Greece has the largest percentage of island population and area, from all EU countries. Its substantial difference from the second Italy is that the Greek island area is scattered and consists of very small islands, which adds to the problem of insularity.

Greek tourism largely depends on those insular regions, as demonstrated by the latest statistical research (Bank of Greece, 2016), which shows that the importance of insularity in the broader Greek tourism is critical and self-evident, given that the Region of Southern Aegean and the Region of Crete hold the top two positions in terms of overnight stays.

More specifically, overnight stays of travelers in Greece amounted to 190,402,000 in 2016. According to the distribution of overnight stays among the 13 regions of the country, $85.1 \%$ of overnight stays involved the following five regions (see Figure 2), with the Region of Southern Aegean ranking first $(39,996,000)$, followed by the Regions of Crete $(39,378,000)$, Central Macedonia $(36,330,000)$, Attica $(24,769,000)$ and the Ionian Islands $(21,493,000)$. In the remaining eight regions, there were 28,437,000 overnight stays (Bank of Greece, 2016).

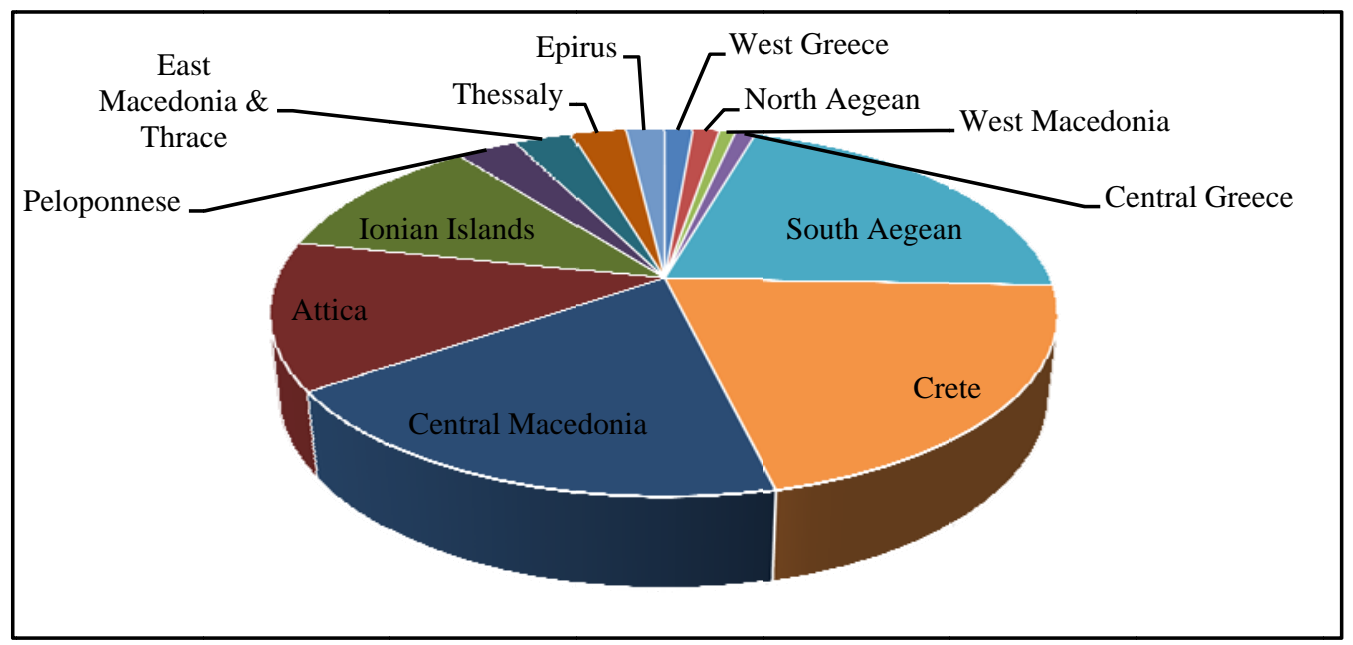

Figure 2. Allocation of overnight stays per region (2016). Source: Bank of Greece (2016). 


\section{Tourism and Insular Economy. The Problem with the Increase in the VAT}

The characteristics of the "Insular Economy" involve primarily lack of cohesion of the insular region, resulting in greater cost of transportation and living in general (Papadaskalopoulos, 2016). In more general terms, in 2013-2014, the average declared income in insular municipalities amounted to $€ 13,400$, while the average declared income nationwide amounted to $€ 15,150$. At the same time, municipalities in the islands show a larger rate of tax statements in low income categories $(<€ 11,738.81)$ compared to the rest of the country, while in the high income categories, insular municipalities fall short of the national average (Papadaskalopoulos, 2016).

Based on gross value added (GVA) data, the three insular regions contribute $23.72 \%$ to the total tourism GVA of the country. Moreover, in Table 1, it is demonstrated the development of National GDP and the three insular regions contribution GDP as a percentage to the national one.

Table 1

Development of Insular GDP and Participation in the National GDP

\begin{tabular}{llll}
\hline & 2000 & 2008 & 2013 \\
\hline Regions of the North and South Aegean and the Ionian Islands & 9,383 & 16,219 & 11,449 \\
Greece & 141,247 & 241,990 & 180,389 \\
Percentage of country's GDP (\%) & 6.64 & 6.70 & 6.35 \\
\hline
\end{tabular}

Note. Source: Hellenic Statistical Authority (2015).

\section{The Issue of VAT Increase in Tourism}

The tourism industry in Greece, which involves the promotional activity of the islands' economy, the tourism businesses are burdened by a significant increase in VAT rates compared to competitive countries. If this increase is rolled over to customers, the Greek tourism packages will automatically become more expensive, while if it is absorbed by the businesses, then many of them will become non-viable.

In particular, Greece has the highest burden in all sectors of tourist interest compared to the competitive EU countries such as Spain, France, Croatia, Italy, Cyprus, Malta, Portugal and Slovenia (see Table 2).

Table 2

Comparison of VAT Rates with Other Countries

\begin{tabular}{|l|l|}
\hline Country & VAT status \\
\hline Greece & $\begin{array}{l}\text { The } 30 \% \text { reduction in the Greek Islanding Area is abolished. The rates applied in the mainland (24\%, } \\
13 \% \text { and 6\%) applied in islands too }\end{array}$ \\
\hline Spain & Canary Islands: Exemption from VAT \\
\hline France & Overseas Islands: Rates from $1.05 \%$ to $8.5 \%$ \\
\hline Portugal & $\begin{array}{l}\text { Reduced rates applied to the Azores and Madeira } \\
\text { Azores: } 5 \%, 10 \%, 18 \% ; \text { Madeira: } 5 \%, 12 \%, 22 \% \text {, versus } 6 \%, 13 \% \text { and 23\% of the country }\end{array}$ \\
\hline Denmark & Faeroe Islands and Greenland: Exemption from VAT \\
\hline Germany & Helgoland Island: Exemption from VAT \\
\hline Finland & The Isle of Aland Islands: Exemption from VAT \\
\hline
\end{tabular}

Note. Source: European Commission (2016).

The VAT rates in Greece are also much higher than those applied in existing or potential tourism competitors in the Mediterranean, such as Turkey, Morocco, Tunisia, Albania, Algeria, Egypt, Israel, and Montenegro. 
Table 3

Indicative VAT Rates in Tourism Sectors (2016) in Neighboring Countries

\begin{tabular}{llllll}
\hline Country & Hotels & Food & $\begin{array}{l}\text { Passenger } \\
\text { transportation }\end{array}$ & Dietary products & $\begin{array}{l}\text { Entrance to recreation } \\
\text { areas }\end{array}$ \\
\hline Greece & $13 \%$ & $24 \%$ & $24 \%$ & $13 \% / 24 \%$ & $24 \%$ \\
Spain & $10 \%$ & $10 \%$ & $10 \%$ & $10 \%$ & $21 \%$ \\
France & $10 \%$ & $10 \%$ & $10 \%$ & $5.5 \% / 10 \% / 20 \%$ & $10 \% / 20 \%$ \\
Croatia & $13 \%$ & $13 \%$ & $25 \%$ & $5 \% / 13 \% / 25 \%$ & $25 \%$ \\
Italy & $10 \%$ & $10 \%$ & $10 \%$ & $4 \% / 10 \%$ & $22 \%$ \\
Cyprus & $9 \%$ & $9 \%$ & $19 \%$ & $5 \% / 19 \%$ & $5 \%$ \\
Malta & $7 \%$ & $18 \%$ & $0 \%$ & $0 \%$ & $18 \%$ \\
Portugal & $6 \%$ & $13 \%$ & $8 \%$ & $5 \% / 8 \% / 20 \%$ & $8 \%$ \\
\hline
\end{tabular}

Note. Source: European Commission (2016).

The reduced VAT regime, whereby the national VAT rate is reduced by 30\% (From 13\% to 5\% for the low rate, from $13 \%$ to $9 \%$ for the middle rate, and from $24 \%$ to $17 \%$ for the high rate), must be promptly re-established in the islands (see Table 3). This regime, along with the classification of insular regions as less developed EU regions so that they can receive additional aid, will help strengthen the socio-economic sustainability and cohesion of the Greek Insular Area (European Commission, 2016).

\section{Overview of Tourism Statistics}

The major aggregate results of the Greek tourism industry for 2016 are as follows.

Visits of travelers per region. In 2016, the travelers who visited Greece made 28,376,000 visits to the 13 regions of the country. This number is higher than the total incoming passenger traffic (2016: 24,799,000).

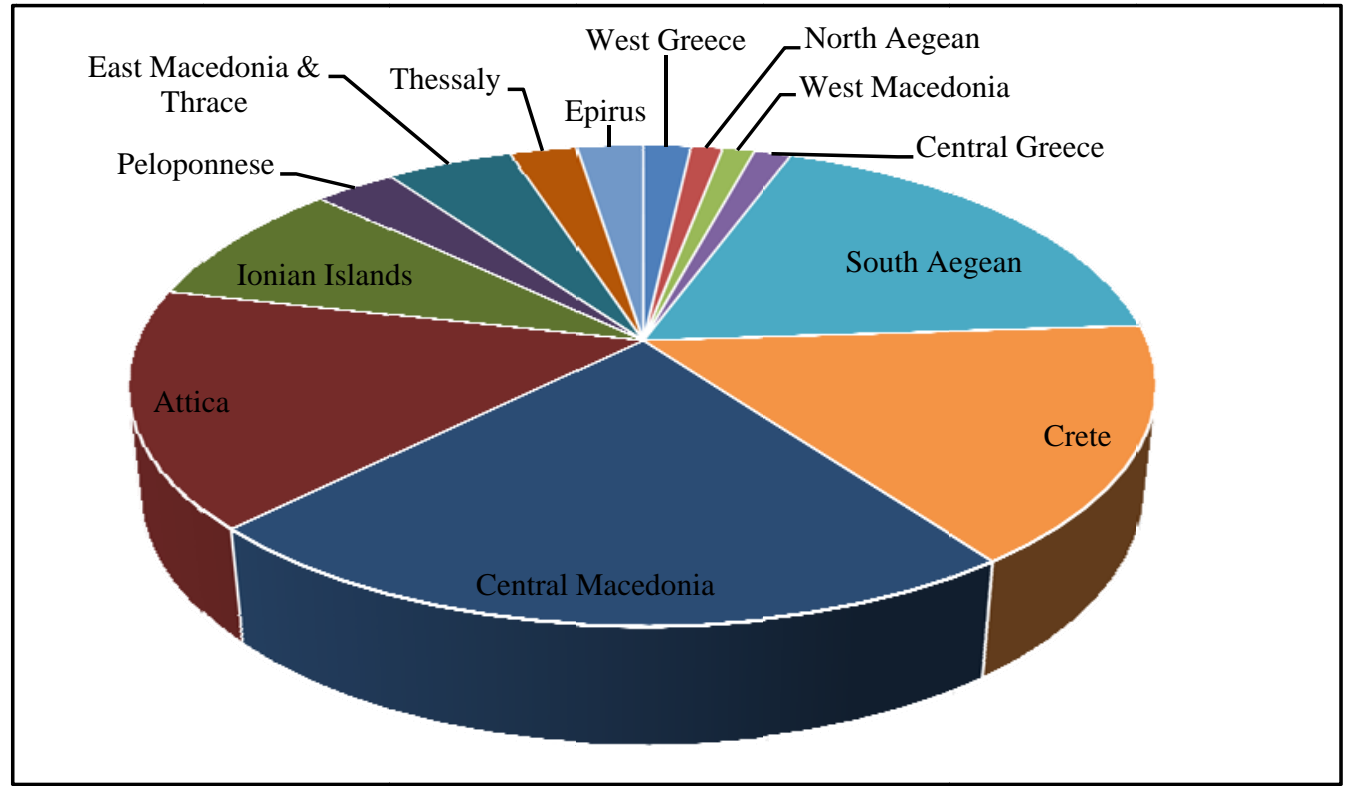

Figure 3. Distribution of visits per region in 2016. Source: Bank of Greece (2016).

Proceeds from Travelers per Region. In 2016, the proceeds from travelers amounted to EUR 12,749 million. As shown in Figure 4, the main volume of proceeds, at a rate of $87.5 \%$ of the total, was generated in the following five regions: Southern Aegean (EUR 3,136 million), Crete (EUR 3,095 million), Attica (EUR 1,734 million), Central Macedonia (EUR 1,688 million), and the Ionian Islands (EUR 1,504 million). 


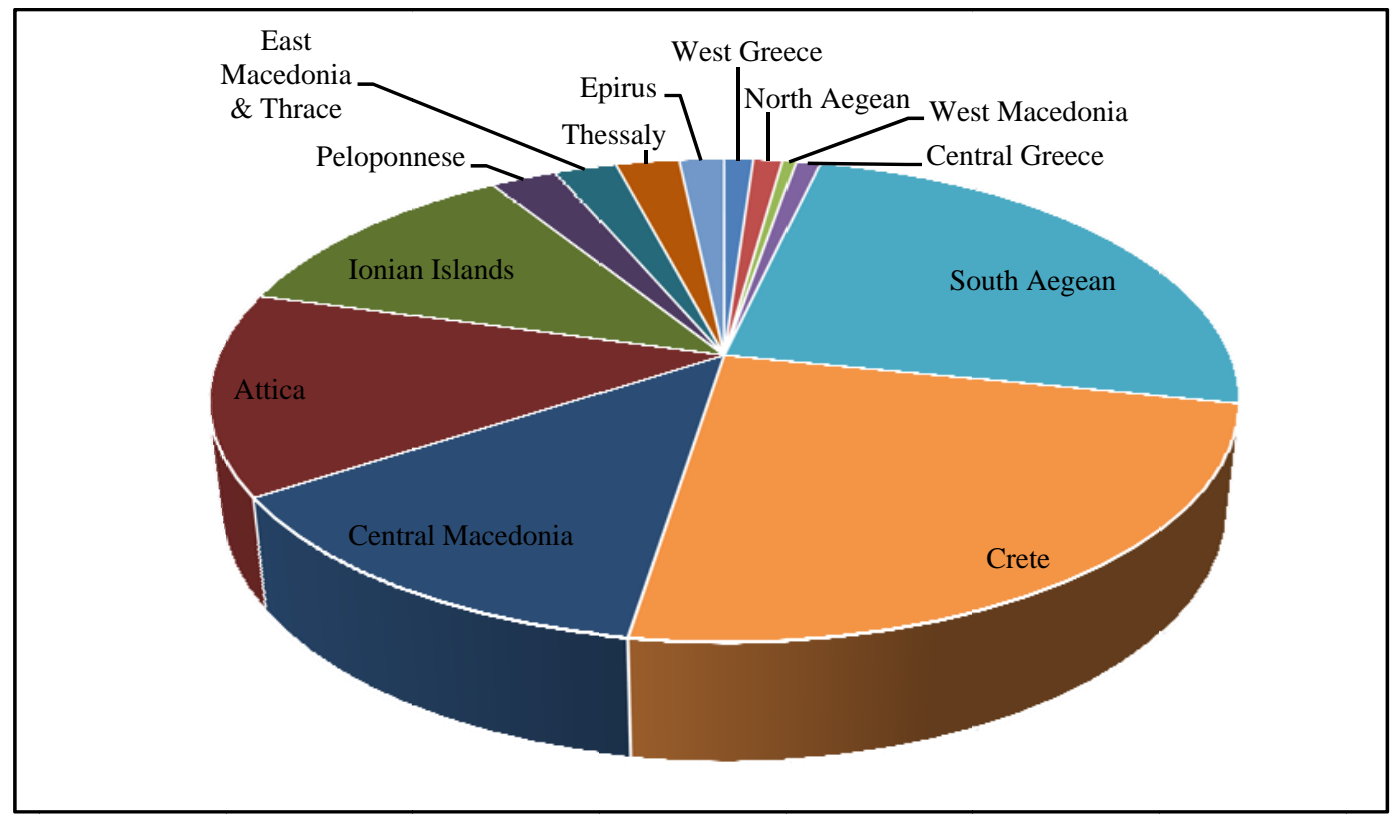

Figure 4. Distribution of traveler proceeds per region. Source: Bank of Greece (2016).

In the remaining eight regions, the proceeds amounted to a total of EUR 1,592 million (Bank of Greece, 2016). The nationality of travelers who visited Greece in 2016 ranked by numbers (from 1st to 10th position) is the following: From the United Kingdom: 3,278,880 arrivals by plane (+251,305 compared to 2015). From Germany: 2,867,417 (+198,101), Italy: 1,560,468 (+116,271), France: 1,082,806 (+30,213), Russia: 819,986 $(+143,841)$, the Netherlands: 745,731 (+49,786), Poland: 728,374 $(+94,938)$, Cyprus: 726,859 $(+28,738)$, Switzerland: 642,515 (+43,715), and Sweden: 568,147 (+26,418).

The Athens airport ranked the 1st in arrivals by plane in 2016, with 6.4 million passengers, followed by the airports of Heraklion and Rhodes, with 2.8 million passengers and 2 million passengers, respectively.

The quite significant "tourism trends" of the residents of the EU were noted by the Eurobarometer, the major reason for vacationing in Greece being the Sun/Sea with a rate of $39 \%$ and visiting family/friends/relatives with a rate of $38 \%$. About three out of 10 respondents cited as the main reason nature (31\%), city breaks (27\%), and culture (26\%), while about one out of 10 respondents indicated wellness, health, spa, or treatment (13\%), sports (12\%), or a specific event (9\%).

The most important reasons for which Europeans would revisit a destination rank as follows: (1) nature (landscape, climate, etc.), 45\%; (2) quality of accommodation facilities, 32\%; (3) cultural and historical sites, 31\%; (4) price levels, 24\%; (5) hospitality services, 21\%; (6) available activities/services, 20\%; and (7) services for persons with special needs, 6\% (Spilanis et al., 2010).

\section{Case Study: Tourism in Southern Aegean}

The RSA, due to its position, is the south-easternmost border of Greece and Europe. In the past few years, as a result of the broader geostrategic upheaval in the area of the Eastern Mediterranean (civil war in Syria, turmoil following the attempted coup in Turkey, etc.), the RSA has emerged as a critical European insular region, since the South and East Aegean islands were the ones that accepted the heaviest burden of refugee flows. 
In 2015, these areas experienced the largest refugee flow after the Second World War. One third of the total refugee and immigrant flows towards Europe passed through the islands of the South Aegean, and primarily through the Dodecanese islands of Rhodes, Kos, Leros, Kalymnos, Symi, etc., which accepted hundreds of thousands of refugees.

However, tourism did not collapse under the burden of the refugee crisis; on the contrary, the South Aegean saw an upward development, mainly because the RSA moved along three axes:

(1) The first one, being the management of the refugee crisis in the conditions of humanism and relief for hundreds of thousands of displaced persons who reached the shores of South Aegean islands;

(2) The second one, being the provision of support to small insular communities;

(3) The third one, involving the protection of the international image of the islands, which determines the overall image of Greece, and thus, the overall course of Greek tourism (Dimokratiki, 2017).

In addition to the refugee crisis, the basic problems (weaknesses and threats) and benefits (strengths and opportunities) of the RSA are shown in the following SWOT analysis in Table 4. Moreover, strategic directions through five-step policy implications for local development and tourism are introduced.

Table 4

SWOT Analysis

\begin{tabular}{|c|c|}
\hline Strengths & Weaknesses \\
\hline $\begin{array}{l}\text { 1. Specialization in: tourism - agriculture - aquaculture - } \\
\text { processing of agricultural products - transport and construction } \\
\text { 2. High-quality natural environment } \\
\text { 3. Significant cultural assets } \\
\text { 4. Favorable natural environment for renewable energy sources } \\
\text { 5. Significant number of ports and airports } \\
\text { 6. Large IT penetration in businesses } \\
\text { 7. Population increase and high percentage of economically } \\
\text { active population } \\
\text { 8. Many islands have a powerful brand name in tourism } \\
\text { 9. Second richest region in Greece } \\
\text { 10. High indices of biodiversity in the broad marine area } \\
\text { 11. Significant internal market thanks to tourism }\end{array}$ & $\begin{array}{l}\text { 1. Triple insularity } \\
\text { 2. High cost of transportation } \\
\text { 3. Serious deficiencies in water resources and energy } \\
\text { 4. Low education level of employees and low rate of } \\
\text { degree-holders among the population } \\
\text { 5. Low participation in life-long learning } \\
\text { 6. Low investments in research on the part of businesses } \\
\text { 7. Low capacity of businesses to absorb innovations } \\
\text { 8. Specialization in only one sector due to tourism, and lack of } \\
\text { significant variety in economy } \\
\text { 9. Domination of mass tourism } \\
\text { 10. Digital seclusion of small islands and settlements }\end{array}$ \\
\hline Opportunities & Threats \\
\hline $\begin{array}{l}\text { 1. Differentiation of tourism product and development of } \\
\text { experience tourism } \\
\text { 2. Utilization of synergies with agriculture-food } \\
\text { industry-livestock farming } \\
\text { 3. Development of IT applications and services, in particular } \\
\text { about tourism } \\
\text { 4. Development and application of integrated marine } \\
\text { environment management systems } \\
\text { 5. Development of renewable energy sources }\end{array}$ & $\begin{array}{l}\text { 1. Adverse economic environment due to the economic crisis } \\
\text { 2. Significant obstacles to entrepreneurship } \\
\text { 3. Significant international competition in the specialization } \\
\text { sectors, particularly due to cost and lack of variety in the local } \\
\text { production } \\
\text { 4. Retention of the cost of production and transportation at high } \\
\text { levels due to fuel prices } \\
\text { 5. Delays in the energy interconnection of islands } \\
\text { 6. Delays in the implementation of the National Strategy for Digital } \\
\text { Development, which will broaden the digital gap of small islands }\end{array}$ \\
\hline
\end{tabular}

Note. Source: Authors (2017).

\section{Improvement of the Destination Management of the RSA}

Five policy steps are required in order to deal with the threats in the RSA, identified in the study of the capacities and weaknesses of the tourism industry.

The first step involves actions in support of the mass summer tourism, which includes actions such as improvement of accommodation facilities and tourist services offered, upgrade of supplementary health and transport services, with concurrent promotion of local food products, and improvement of local government services (Cleanliness - Reconstructions - Control - Infrastructures - Networks, etc.). 
The second step involves enriching the tourist product through actions such as promotion of the architectural heritage, archaeological resources, local events (feasts - festivals), areas of natural beauty (information about special areas and routes), areas of "industrial archaeology", museums, and virtual reality centers, which are significant innovative in tourism industry (Papadaskalopoulos, 2016).

The third step involves promotion of alternative forms of tourism, with integration of the following actions in the basic tourist product per insular municipality, not only as evolving policies but also as practicable implemented tasks.

Table 5

Enrichment of the Tourist Product by Type of Tourism

\begin{tabular}{|c|c|c|c|c|c|}
\hline Cultural tourism & Spa tourism & \begin{tabular}{|l} 
Athletic and \\
maritime tourism
\end{tabular} & Natural tourism & \begin{tabular}{|l|}
$\begin{array}{l}\text { Conference and } \\
\text { educational tourism }\end{array}$ \\
\end{tabular} & Religious tourism \\
\hline $\begin{array}{l}\text { Familiar with traditional } \\
\text { activities, products and } \\
\text { customs }\end{array}$ & $\begin{array}{l}\text { Exploitation of } \\
\text { thermal springs }\end{array}$ & Exploiting marinas & \begin{tabular}{|l|} 
Historical and \\
natural walks hiking \\
routes
\end{tabular} & $\begin{array}{l}\text { Conference and } \\
\text { educational areas }\end{array}$ & \begin{tabular}{|l} 
Restorations of \\
Byzantine \\
monuments of \\
religious interest \\
\end{tabular} \\
\hline Wine routes & Spa networking & $\begin{array}{l}\text { Exploitation of } \\
\text { nautical sport } \\
\text { infrastructure }\end{array}$ & $\begin{array}{l}\text { Nature observation } \\
\text { Bird watching }\end{array}$ & $\begin{array}{l}\text { Educational and } \\
\text { conference actions } \\
\text { for tourism } \\
\text { products } \\
\text { (e.g., shipping) } \\
\end{array}$ & $\begin{array}{l}\text { Program for the } \\
\text { promotion of } \\
\text { religious monuments }\end{array}$ \\
\hline $\begin{array}{l}\text { Technology and science } \\
\text { of the ancient Greeks }\end{array}$ & $\begin{array}{l}\text { Exploitation of } \\
\text { geothermal field }\end{array}$ & $\begin{array}{l}\text { Exploitation of } \\
\text { coastal zone }\end{array}$ & $\begin{array}{l}\text { Geological } \\
\text { tourism/caves }\end{array}$ & $\begin{array}{l}\text { Technologically } \\
\text { innovative } \\
\text { educational and } \\
\text { conference facilities }\end{array}$ & $\begin{array}{l}\text { Network of } \\
\text { Byzantine } \\
\text { monuments }\end{array}$ \\
\hline $\begin{array}{l}\text { Highlight of nautical } \\
\text { character }\end{array}$ & $\begin{array}{l}\text { Tourism } \\
\text { wellness }\end{array}$ & Diving tourism & Botanical garden & \begin{tabular}{|l|}
$\begin{array}{l}\text { Hydrobiological } \\
\text { station }\end{array}$ \\
\end{tabular} & $\begin{array}{l}\text { Exploitation of } \\
\text { castles }\end{array}$ \\
\hline $\begin{array}{l}\text { Highlight of medieval } \\
\text { character }\end{array}$ & & Water sports & $\begin{array}{l}\text { Traditional } \\
\text { activities/buildings }\end{array}$ & & \\
\hline
\end{tabular}

Note. Source: Authors (2017).

The fourth step should involve targeted and prompt actions to enhance the cooperation of local government officials with the state, professional associations, active citizen bodies, and each person participating actively in tourism activity. The implementation of those steps must begin at the insular municipality level reaching up to the central state administration.

Finally, the fifth step requires the elaboration and promotion of an integrated tourism development package, through image-promotion and branding per insular municipality. The promotion of Greece is important mainly on tourism markets abroad, and among the visitors of the island (Papadaskalopoulos, 2016).

In the last two years, the central motto of tourism promotion of the RSA was "Aegean Islands - Like No Other". Today, the promotion actions are enriched with the motto "I choose South Aegean for every special moment”, mainly aiming at:

(1) The promotion of the uniqueness of each island separately;

(2) The promotion of the experiences it offers to each visitor;

(3) The strengthening of the new forms of tourism;

(4) The connection of the tourist product of the South Aegean with specialized experiences in culture, sea sports (e.g., sailing), gastronomy, religious tourism, with a view to upgrading quality and increasing the number of visitors. 
The promotion of geopolitical safety and stability in the area, along with the upgrade of the insular and hotel infrastructures, in combination with the creation of new travel experiences constitute the three most basic prerequisites in order for tourism in the Region of Southern Aegeanto have a future. Thus, on the one hand, the RSA will offer what it can to the national effort of overcoming the crisis, and on the other hand, it will upgrade the local economy and hence, the local community (Region of Southern Aegean, 2017).

\section{Conclusions}

Insularity is the relative seclusion of the insular areas compared to continental regions, resulting in incomplete access to markets and public services, problematic movement of people and goods, uneven development of the productive capacity and the living conditions.

Despite the intense insularity of Greece, the insular regions of South Aegean and Crete held the first two positions in overnight stays of tourists in 2016, respectively. Nevertheless, insular municipalities generated an average declared income of $€ 13,400$ per resident, while the average declared income nationwide amounted to $€ 15,150$, with the insular regions of Northern and Southern Aegean and the Ionian Islands participating with 23.72\% in the total tourism GVA of Greece.

The recent political decision to increase the VAT on tourism creates critical problems to the tourist industry, given that in Greece all tourism-related sectors have the highest burden compared to competitive EU countries such as Spain, France, Croatia, Italy, Cyprus, Malta, Portugal and Slovenia.

The Overview of Tourism Statistics for 2016 shows that the travelers who visited Greece totaled 28,376,000, the proceeds from travelers amounted to EUR 12,749 million (with the RSA ranking first in proceeds, with EUR 3,136 million), most of the visitors came from the United Kingdom, Germany, Italy and France, with the Athens airport ranking first in arrivals, with 6.4 million visitors. Finally, the main reason for which EU citizens chose Greece for their vacation was the sun/sea with a rate of $39 \%$, and visiting family/friends/relatives with $38 \%$.

Five policy steps are proposed for dealing with the threats in the region of Southern Aegean, identified in the study of the capacities and weaknesses of the tourism industry:

(1) Mass summer tourism support actions;

(2) Enrichment of the tourism product through new actions (see Table 5);

(3) Promotion of alternative forms of tourism;

(4) Targeted actions towards strengthening cooperation between all the parties involved in tourism;

(5) The elaboration - promotion of an integrated tourism development package.

In the last two years, the central motto of tourism promotion of the RSA was "Aegean Islands - Like No Other", and currently, the promotion actions are enriched with the motto "I choose South Aegean for every special moment”. In conclusion, the three major prerequisites for strengthening tourism in the RSA involve promoting geopolitical safety and stability in the area, upgrading insular and hotel infrastructures, and finally, creating and implementing new travel experiences.

\section{References}

Bank of Greece. (2016). Regional distribution of travel receipts as well as visits and overnight stays of incoming travelers. Athens, Greece.

Dimokratiki. (2017). The revenues from tourism the key factor for GDP development. Journal of Rhodes. (in Greek) 
European Commission. (2016). VAT rates applied in the Member States of the European Union. Taxud.c.1.(2017) - EN. European Commission.

European Social Fund in Greece. (2017). How it is implemented in Greece. Retrieved from http://www.esfhellas.gr/en/Pages/Default.aspx

Georgopoulos, N. (2013). Strategic management. Athens: Publications G. Benou.

Hellenic Statistical Authority. (2015). Development of Insular GDP and participation in the national GDP. Hellenic Statistical Authority. Retrieved from https://www.statistics.gr (in Greek)

Institution of Municipalities. (2016). Insular policy. Institution of Municipalities/Central Union of Greek Municipalities, Athens, Greece.

Papadaskalopoulos, A. (2016). Island policy - Local government and insularity. Greece: Institute of Local Government. (in Greek) Sarantakos, N. (2015). Islands and insularity. Retrieved from https://sarantakos.wordpress.com/2015/06/17/insularity/ (in Greek) Secretariat General for the Aegean and Island Policy. (2012). Island policy: Strategic and business planning. Greece.

Spilanis, I., Akrikopoulou, I., Gakis, K., Michailidis, G., \& Niarchos, A. (2010). Kallikrates in the islands. EETT. Athens, Greece. 